Info Artikel:

Diterima: $17 / 11 / 2017$

Direvisi: $25 / 12 / 2017$

Dipublikasikan: 26/01/2018

Dipublikasikan oleh :

Indonesian Institute for Counseling, Education and Therapy (IICET)

Akses Online :

http://jurnal.iicet.org

\title{
Peningkatan Pemahaman Konsep IPA Melalui Metode Eksperimen Pada Siswa Kelas V SDN 01 Sungai Geringging Kabupaten Padang Pariaman Yarnis
}

\begin{abstract}
Abstrak
Penelitian ini berawal dari kenyataaan di sekolah bahwa siswa dalam proses pembelajaran hanya pasif mendengarkan apa yang disampaikan oleh guru. Siswa ribut dan beberapa orang siswa asik bermain dengan teman sebangkunya. Siswa kurang dapat berkonsentrasi sehingga pemahaman konsep IPA tidak begitu berkembang. Hal ini dapat diatasi melalui metode eksperimen karena siswa terlibat langsung dalam proses pembelajaran. Penelitian ini menggunakan jenis penelitian tindakan kelas. Subjek penelitian ini adalah siswa kelas V SDN 01 Sungai Geringging. Berdasarkan hasil penelitian yang diperoleh bahwa metode eksperimen dapat meningkatkan pemahaman konsep IPA. Menggunakan metode ini juga dapat meningkatkan aspek afektif dan psikomotor siswa. Dengan demikian dapat disimpulkan bahwa metode eksperimen dapat meningkatkan kompetensi kognitif, afektif dan psikomotr siswa kelas V SDN 01 Sungai Geringing.
\end{abstract}

Kata kunci: Pemahaman Konsep, IPA, Metode Eksperimen

Copyright @ 2018 IICET - All Rights Reserved

Indonesian Institute for Counseling, Education and Theraphy (IICET)

\section{PENDAHULUAN}

Ilmu Pengetahuan Alam (IPA) merupakan kumpulan dari ilmu-ilmu eksakta yang tersusun secara sistematis. Pada pembelajaran IPA (Ilmu Pengetahuan Alam) siswa dituntut aktif dalam belajar, karena materi IPA merupakan serangkaian kegiatan proses ilmiah antara lain penyelidikan (eksperimen), penyusunan dan pengkajian gagasan serta konsep.

Pembelajaran IPA dapat menjadi wahana bagi siswa untuk mempelajari diri sendiri dan alam sekitarnya, sehingga mereka mendapatkan manfaat mempelajari IPA untuk diterapkan dalam kehidupan sehari-hari dan kehidupan masa yang akan datang. Depdiknas (2006:484) mengatakan bahwa pembelajaran IPA SD bertujuan untuk menumbuhkan kemampuan berfikir, bekerja dan bersikap ilmiah, serta mengkomunikasikannya sebagai aspek penting kecakapan hidup. Pembelajaran IPA SD hendaklah didesain dengan baik sehingga siswa dapat memahami materi yang telah dipelajari. Good \& Brophy (dalam Sunaryo, 1996:61) anak usia SD adalah anak yang usianya berkisar antara 7-12 tahun, dan berada pada tahap perkembangan operasional konkret. Siswa pada tahap operasional konkret akan lebih memahami apa yang dialaminya atau dilihatnya secara nyata. Oleh sebab itu dalam pembelajaran IPA SD ada hal-hal pokok yang harus diperhatikan guru dalam pembelajaran. Hal ini diungkapan oleh Usman (2006:5) bahwa dalam pembelajaran IPA ada beberapa aspek yang harus diperhatikan guru antara lain: 1) pentingnya memahami bahwa pada saat memulai kegiatan pembelajaran IPA, siswa telah memiliki berbagai 
konsepsi pengetahuan yang relevan dengan apa yang mereka pelajari, 2) aktivitas siswa melalui berbagai kegiatan nyata dengan alam menjadi hal utama dalam pembelajaran IPA, 3) bertanya merupakan ciri utama dalam pembelajaran IPA dan memiliki peran penting dalam upaya membangun pengetahuan selama pembelajaran, 4) pembelajaran IPA memberikan kesempatan kepada siswa untuk mengembangkan kemampuan berpikirnya dalam menjelaskan suatu masalah.

Melihat pada aspek IPA yang telah dikemukakan, dapat disimpulkan bahwa IPA adalah ilmu pengetahuan yang bersifat ilmu pasti yang meliputi berbagai aspek kehidupan yang diperoleh melalui pemikiran manusia yang logis dan terstruktur. Di samping itu IPA juga bertujuan supaya siswa memiliki pemikiran, dan pengetahuan yang dapat dijadikan modal dasar untuk IPA yang lebih tinggi, serta memiliki keterampilan yang dapat dimanfaatkan dalam kehidupan sehari-hari.

Namun kenyataan yang penulis temui di lapangan berbeda dengan yang seharusnya. Berdasarkan hasil pengamatan khususnya dalam pembelajaran IPA di kelas V SD Negeri 01 Sungai Geringging, penulis belum sepenuhnya melibatkan siswa secara aktif. Selain itu penulis juga lebih cenderung menggunakan pendekatan konvensional dari awal pembelajaran sampai berakhirnya pembelajaran IPA. Ketimpangan-ketimpangan ini juga terlihat dari segi penggunaan metode pembelajaran yang dilaksanakan. Guru belum mampu memilih metode yang sesuai dengan materi yang diajarkan. Sedangkan metode pembelajaran itu sangat erat kaitannya dengan pencapaian tujuan pembelajaran yang sudah ditetapkan.

Keadaan ini berdampak pada siswa yang terlihat pasif dan tidak bersemangat. Siswa juga terlihat bosan selama pembelajaran berlangsung dan mereka tidak ada yang bertanya walau pun belum mengerti. Hal ini menyebabkan pemahaman konsep IPA siswa rendah. Ini terbukti ketika guru mengajukan pertanyaan sebagian siswa tidak bisa menjawab. Untuk peningkatan pemahamaan konsep IPA oleh siswa, guru harus dapat memilih metode yang sesuai dengan materi yang diajarkan. Banyak metode pembelajaran yang dapat digunakan dalam pembelajaran IPA, salah satunya adalah metode eksperimen.

Penggunaan metode eksperimen akan membuat siswa paham dan mengerti dengan apa yang dipelajarinya karena mereka terlibat langsung dalam proses pembelajaran. Syahruddin (2008:18) mengatakan bahwa dengan bereksperimen siswa akan memahami konsep suatu pembelajaran apalagi materinya berhubungan dengan hal-hal nyata yang terdapat di lingkungan siswa. Berdasarkan permasalahan yang telah diuraikan di atas, penulis tertarik untuk melakukan sebuah penelitian tindakan kelas dengan judul "Peningkatan Pemahaman Konsep IPA Melalui Metode Eksperimen Pada Siswa Kelas V SDN 01 Sungai Geringging Kabupaten Padang Pariaman. Rumusan masalah dalam penelitian ini adalah Bagaimana pelaksanaan pembelajaran untuk peningkatan pemahaman konsep IPA melalui metode eksperimen pada siswa kelas V SDN 01 Sungai Geringging Kabupaten Padang Pariaman?

\section{METODE}

Penelitian Penelitian yang dilakukan merupakan penelitian tindakan kelas dengan menggunakan pendekatan kualitatif. Lokasi penelitian adalah SDN 01 Sungai Geringging Kabupaten Padang Pariaman. Subjek penelitian adalah siswa kelas V yang berjumlah 25 orang. Tindakan yang dilakukan dalam penelitian ini adalah.

1. Mempersiapkan pemakaian metode eksperimen:

a. menetapkan kesesuaian metode eksperimen dengan tujuan yang akan dicapai.

b. menetapkan kebutuhan peralatan, bahan, dan sarana lainnya.

c. mengadakan uji eksperimen sendiri.

d. menyediakan peralatan, bahan dan sarana lain. 
e. menyediakan lembaran kerja siswa.

2. Melaksanakan pemakaian metode eksperimen:
a. Mendiskusikan tentang eksperimen yang akan dilakukan.
b. Melakukan eksperimen
c. Membuat kesimpulan dan laporan eksperimen.

3. Tindak lanjut dari penggunaan metode eksperimen:
a. Mendiskusikan hambatan dan hasil-hasil eksperimen.
b. Membersihkan dan menyimpan peralatan lainnya.
c. Evaluasi akhir eksperimen

\section{HASIL PENELITIAN DAN PEMBAHASAN}

\section{Hasil Penelitian}

\section{Siklus I}

\section{Perencanaan}

Pada tahap ini, peneliti berkolaborasi dengan kepala sekolah, membuat persiapan yang terdiri dari rencana pelaksanaan pembelajaran dan lembar pengamatan. Sedangkan instrumen pengumpulan data yang digunakan adalah instrumen observasi rambu-rambu karakteristik pembelajaran. Materi pembelajaran yang dilaksanakan pada siklus I adalah pembelajaran Pesawat sederhana jenis tuas dengan menggunakan metode eksperimen. Kompetensi Dasar yang ingin dicapai pada materi ini adalah menjelaskan pesawat sederhana yang dapat membuat pekerjaan lebih mudah dan lebih cepat.

Indikator yang ingin dicapai pada siklus 1 adalah a) menyebutkan berbagai jenis pesawat sederhana misalnya tuas, bidang miring, roda, dan katrol, b) mengidentifikasi berbagai jenis tuas yaitu tuas golongan pertama, tuas golongan kedua, tuas golongan ketiga, c) menjelaskan ciri-ciri tuas menurut golongannya, d) mengidentifikasi kegiatan yang menggunakan pesawat sederhana jenis tuas. Penilaian terhadap pembelajaran dengan melaksanakan tes di akhir pembelajaran pada siklus I untuk melihat keberhasilan dari siklus I.

\section{Pelaksanaan}

Pelaksanaan pembelajaran mengikuti langkah-langkah pembelajaran dengan metode eksperimen. Untuk lebih jelasnya, pelaksanaan pembelajaran ini diuraikan sebagai berikut:

Siklus I membahas mengenai pengertian pesawat sederhana, jenis-jenis pesawat sederhana, mengidentifikasi berbagai jenis tuas, ciri-ciri tuas/pengungkit golongan $\mathrm{I}$ dan mengidentifikasinya, prinsip kerja tuas golongan I. Pada awal pembelajaran, guru mengabsen siswa dan menyampaikan tujuan pembelajaran. Guru mengajukan pertanyan "Apakah anakanak pernah melihat atau melakukan permainan jungkang jungkit?" kemudia melakukan tanya jawab mengenai jungkat jungkit. 
Pada kegiatan inti, guru membentuk lima kelompok belajar. Masing-masing anggota kelompok terdiri dari 5 orang siswa. Guru membagikan LKS 1 dan bahan percobaan yaitu kaleng yang tertutup dan obeng pipih kepada masing-masing kelompok. Perwakilan masingmasing kelompok mengambilnya ke depan kelas. Kemudian guru meminta siswa untuk terlebih dahulu membaca dan memahami LKS I. Serta memberikan kesempatan kepada siswa untuk bertanya jika ada yang kurang mengerti langkah kerja dalam LKS 1. Setelah siswa membaca LKS 1 tidak seorang siswa pun yang bertanya. Hal ini disebabkan karena siswa masih malumalu dan ragu untuk bertanya.

Menyikapi hal itu guru menanyakan tentang cara kerja LKS 1. Ternyata siswa telah memahaminya karena cara kerja yang ada dalam LKS1 merupakan kegiatan yang sudah pernah dialami siswa dalam kehidupannya sehari-hari. Selanjutnya guru meminta siswa untuk melakukan percobaan sesuai dengan LKS1. Siswa melakukan percobaan dalam kelompoknya masing-masing. Pada kegiatan percobaan masih banyak siswa yang bermain dan sebagian siswa ada yang pasif. Hal ini terjadi karena percobaan didominasi oleh siswa yang pintar dan tampak siswa masih malu-malu untuk mengemukakan ide dan pendapatnya. Untuk itu, guru langsung memberikan arahan dan memotivasi siswa untuk bekerja sama dan giat dalam belajar kelompok.

Setelah selesai melakukan percobaan, guru meminta salah satu kelompok untuk membacakan hasil percobaannya ke depan kelas. Kegiatan ini untuk memupuk keberanian dan kepercayaan diri siswa. Di sini terlihat siswa malu-malu dan ragu-ragu untuk menunjuk tangan. Untuk itu, guru memberikan motivasi kepada siswa agar mau dan berani ke depan kelas. Setelah termotivasi oleh guru, akhirnya salah satu kelompok (kelompok 1) mau dan berani untuk membacakan hasil percobaannya ke depan kelas. Guru meminta kelompok lain untuk bertanya dan menanggapi hasil percobaan yang dilaporkan kelompok 1, namun tidak satupun kelompok yang menanggapinya. Lalu guru meminta kelompok 5 untuk melaporkan ke depan kelas dan meminta tanggapan kepada kelompok lain, namun masih tidak ada tanggapan. Ini terjadi karena siswa masih takut serta malu untuk bertanya, menyampaikan ide dan pendapatnya.

Menyikapi semua itu, guru melakukan tanya jawab dengan siswa tentang hasil percobaan yang sudah dilakukan dan meminta siswa memperbaiki jawabannya jika ada yang kurang tepat. Selanjutnya, guru melakukan tanya jawab dengan siswa mengenai ciri-ciri tuas/pengungkit golongan I berdasarkan percobaan yang telah dilakukan tadi. Terlihat siswa masih ragu-ragu dalam menyampaikan pendapatnya. Namun dengan motivasi dari guru, siswa mampu menyebutkan ciri-ciri tuas/pengungkit golongan I meskipun belum sempurna. Untuk itu, guru menjelaskan kembali ciri-ciri tuas/pungungkit golongan I berdasarkan jawaban dari siswa, yaitu titik tumpu berada diantara kuasa dan beban. Setelah itu, guru menugasi masing-masing wakil kelompok untuk mengumpulkan LKS 1 serta alat dan bahannya ke depan kelas.

Pelaksanaan kegiatan akhir dengan cara guru meminta siswa untuk duduk pada posisi semula. Siswa segera duduk pada bangkunya masing-masing, namun masih ada beberapa orang siswa yang bermain dan guru langsung menegurnya. Selanjutnnya guru melakukan tanya jawab dengan siswa untuk membimbing siswa menyimpulkan pelajaran.

\section{Pengamatan}

Aspek yang diamati adalah:

\section{Aktifitas guru}

Aktifitas guru dalam kegiatan pembelajaran pada siklus I secara umum telah berlangsung sesuai dengan rencana yang telah disusun sebelumnya. Guru telah berhasil melaksanakan pembelajaran yang kontekstual. Kenyataan ini didukung oleh hasil pengamatan aktivitas guru sebagai berikut.

Jurnal Penelitian Pendidikan Indonesia | Akses Online : http://jurnal.iicet.org 
Tabel 1

Aktivitas Guru Siklus I

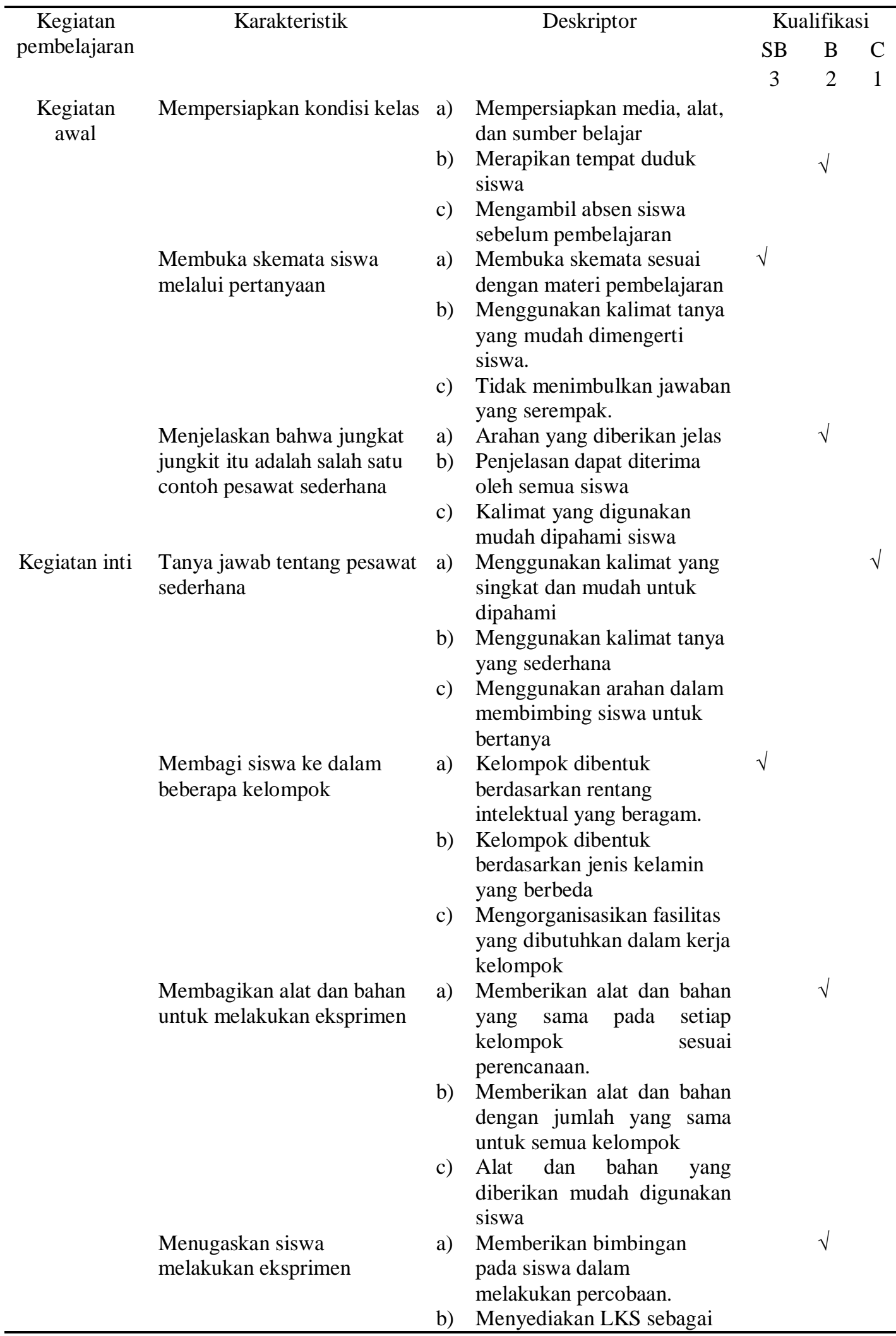

Jurnal Penelitian Pendidikan Indonesia | Akses Online : http://jurnal.iicet.org 
Mengarahkan siswa dalam melakukan eksprimen

Membimbing siswa mengidentifikasi tuas

Kegiatan akhir

\begin{abstract}
Mengarahkan siswa dalam menyimpulkan pembelajaran
\end{abstract}

panduan kerja kelompok.

c) Memberikan kesempatan

kepada siswa utuk menanyakan langkah percobaan yang kurang dipahami.

a) Memantau siswa dalam melakukan eksperimen.

b) Menjelaskan cara melakukan eksperimen.

c) Memotivasi siswa untuk melakukan eksperimen.

a) Memberikan pertanyaan yang sesuai dengan mengidentifikasi tuas.

b) Membimbing siswa dalam mengidentifikasi tuas.

c) Merespon kesulitan siswa yang mengalami kesulitan dalam mengidentifikasi tuas.

a) Mengajukan pertanyaan sesui dengan materi yang dipelajari.

b) Memberikan kesempatan kepada siswa untuk dapat mengungkapkan pengetahuan yang telah dipelajarinya.

c) Memberikan kesempatan untuk mencatat konsep yang dipelajari.

Memberi evaluasi pada siswa

a) Soal sesuai dengan materi yang diajarkan

b) Sesuai dengan tingkat kemampuan siswa

c) Soal mudah dipahami oleh siswa

Memantau siswa dalam menyelesaikan evaluasi

a) Mengkordinir siswa dalam menyelesaikan evaluasi. tersebut

b) Memberikan arahan kepada siswa dalam menyelesaikan evaluasi

c) Mengumpulkan evalusi yang dikerjakan siswa

Berdasarkan tabel 1 terlihat aktivitas guru dalam kegiatan pembelajaran siklus I. Jumlah skor yang diperoleh 26 dari skor maksimal 36, dengan demikian persentase skor rata-rata guru adalah $72,2 \%$. Hal ini menunjukkan bahwa taraf keberhasilan aktivitas guru selama kegiatan pembelajaran berdasarkan hasil pengamatan termasuk dalam kategori baik.

\section{Aktivitas Siswa}

Pada kegiatan pembelajaran siklus I, siswa terlihat kurang antusias dalam mengikuti proses pembelajaran. Kondisi ini terlihat dari hasil pengamatan aktivitas siswa yang dilakukan oleh pengamat dengan berpedoman pada lembaran pengamatan siswa.

Jurnal Penelitian Pendidikan Indonesia | Akses Online : http://jurnal.iicet.org 
Tabel 2.

Aktivitas Siswa Siklus I

\begin{tabular}{|c|c|c|c|c|c|c|}
\hline \multirow{2}{*}{$\begin{array}{c}\text { Kegiatan } \\
\text { pembelajaran }\end{array}$} & \multirow[t]{2}{*}{ Karakteristik } & \multicolumn{2}{|r|}{ Deskriptor } & \multicolumn{3}{|c|}{ Kualifikasi } \\
\hline & & & & SB & $\mathrm{B}$ & $\mathrm{C}$ \\
\hline & & & & 3 & 2 & 1 \\
\hline \multirow[t]{9}{*}{$\begin{array}{l}\text { Kegiatan } \\
\text { awal }\end{array}$} & Mempersiapkan kondisi kelas & a) & $\begin{array}{l}\text { Mempersiapkan sumber } \\
\text { belajar }\end{array}$ & & $\sqrt{ }$ & \\
\hline & & b) & Duduk dengan rapi & & & \\
\hline & & c) & $\begin{array}{l}\text { Mendengarkan absen } \\
\text { sebelum pembelajaran }\end{array}$ & & & \\
\hline & $\begin{array}{l}\text { Membuka skemata siswa } \\
\text { melalui pertanyaan }\end{array}$ & a) & $\begin{array}{l}\text { Mendengarkan pertanyaan } \\
\text { guru }\end{array}$ & & $\sqrt{ }$ & \\
\hline & & b) & $\begin{array}{l}\text { Menjawab pertanyaan } \\
\text { guru. }\end{array}$ & & & \\
\hline & & c) & $\begin{array}{l}\text { Tidak menimbulkan } \\
\text { jawaban yang serempak. }\end{array}$ & & & \\
\hline & $\begin{array}{l}\text { Menjelaskan bahwa jungkat } \\
\text { jungkit itu adalah salah satu }\end{array}$ & a) & $\begin{array}{l}\text { Menyimak penjelasan } \\
\text { guru. }\end{array}$ & & $\sqrt{ }$ & \\
\hline & contoh pesawat sederhana & b) & $\begin{array}{l}\text { Menanyakan hal-hal yang } \\
\text { kurang dipahami. }\end{array}$ & & & \\
\hline & & c) & $\begin{array}{l}\text { Menyebutkan contoh lain } \\
\text { dari pesawat sederhana }\end{array}$ & & & \\
\hline \multirow[t]{15}{*}{ Kegiatan inti } & $\begin{array}{l}\text { Tanya jawab tentang pesawat } \\
\text { sederhana }\end{array}$ & a) & $\begin{array}{l}\text { Menjawab pertanyaan } \\
\text { sesuai dengan materi }\end{array}$ & & & $\sqrt{ }$ \\
\hline & & b) & $\begin{array}{l}\text { Menjawab pertanyaan } \\
\text { dengan lengkap dan jelas }\end{array}$ & & & \\
\hline & & c) & $\begin{array}{l}\text { Bahasa yang digunakan } \\
\text { lugas dan mudah dipahami }\end{array}$ & & & \\
\hline & $\begin{array}{l}\text { Membagi siswa ke dalam } \\
\text { beberapa kelompok }\end{array}$ & a) & $\begin{array}{l}\text { Mengorganisasi anggota } \\
\text { kelompok dengan dengan } \\
\text { tertip. }\end{array}$ & & $\sqrt{ }$ & \\
\hline & & b) & $\begin{array}{l}\text { Mau menerima anggota } \\
\text { kelompoknya. }\end{array}$ & & & \\
\hline & & c) & $\begin{array}{l}\text { Saling berinteraksi antar } \\
\text { anggota kelompok. }\end{array}$ & & & \\
\hline & $\begin{array}{l}\text { Membagikan alat dan bahan } \\
\text { untuk melakukan eksprimen }\end{array}$ & a) & $\begin{array}{l}\text { Mengambil alat } \\
\text { eksperimen dengan tertib. }\end{array}$ & $\sqrt{ }$ & & \\
\hline & & b) & $\begin{array}{l}\text { Menggunakan alat } \\
\text { eksperimen dengan baik. }\end{array}$ & & & \\
\hline & & c) & $\begin{array}{l}\text { Memposisikan alat } \\
\text { eksperimen dengan baik. }\end{array}$ & & & \\
\hline & Siswa melakukan eksprimen & a) & $\begin{array}{l}\text { Melakukan eksperimen } \\
\text { sesuai dengan langkah- } \\
\text { langkah eksperimen. }\end{array}$ & & $\sqrt{ }$ & \\
\hline & & b) & $\begin{array}{l}\text { Saling bekerja sama dalam } \\
\text { melakukan eksperimen. }\end{array}$ & & & \\
\hline & & c) & $\begin{array}{l}\text { Melakukan eksperimen } \\
\text { dengan serius dan teliti. }\end{array}$ & & & \\
\hline & $\begin{array}{l}\text { Mengamati dan mencatat hasil } \\
\text { eksperimen }\end{array}$ & a) & $\begin{array}{l}\text { Mengamati eksperimen } \\
\text { dengan cermat. }\end{array}$ & & $\sqrt{ }$ & \\
\hline & & b) & $\begin{array}{l}\text { Mendiakusikan alat } \\
\text { ekperimen dalam } \\
\text { kelompok. }\end{array}$ & & & \\
\hline & & c) & Mencatat hasil ekperimen & & & \\
\hline
\end{tabular}

Jurnal Penelitian Pendidikan Indonesia | Akses Online : http://jurnal.iicet.org 
dalam LKS

Membimbing siswa mengidentifikasi tuas

Kegiatan akhir
Menyimpulkan pembelajaran

Melaksanakan evaluasi

Mengumpulkan hasil evaluasi a) Mengidentifikasi jenisjenis tuas/ contoh tuas berdasarkan eksperimen.

b) Mengidentifikasi mamfaat tuas berdasarkan eksperimen

c) Mengidentifikasi penggunaan tuas dalam kehidupan kehidupan sehari-hari.

d) Mengidentifikasi jenisjenis tuas/ contoh tuas berdasarkan eksperimen.

e) Mengidentifikasi mamfaat tuas berdasarkan eksperimen

a) Mengidentifikasi penggunaan tuas dalam kehidupan kehidupan sehari-hari.

a) Dilaksanakan secara tertib

b) Evaluasi dilakukan secara beruntun.

c) Sesuai dengan materi pembelajaran

a) Evaluasi dilakukan tepat waktu.

b) Mengumpulkan hasil evaluasi dengan tertib.

c) Menggumpulkan evaluasi dengan berorganisasi.

Berdasarkan hasil pengamatan yang dilakukan terhadap aktivitas siswa dalam kegiatan pembelajaran dapat dipaparkan sebagai berikut: jumlah skor yang diperoleh 23 dari skor maksimal 36. Dengan demikian persentase kegiatan siswa yang sesuai dengan RPP adalah $63,8 \%$. Hal ini terlihat dari kerja siswa dalam belajar kelompok. Selama belajar kelompok berlangsung hanya sebagian kecil siswa yang ikut aktif dan berpartisipasi.

\section{Aspek kognitif}

Keberhasilan pemahaman konsep siswa dilihat dari hasil evaluasi/latihan yang dilakukan pada akhir siklus I. Hasil latihan pada siklus I pembelajaran pesawat sederhana melalui metode eksperimen dapat dilihat pada tabel berikut: 
Tabel 3

Ketuntasan Belajar Siswa

\begin{tabular}{|c|c|c|c|c|c|}
\hline \multirow[t]{2}{*}{ No } & \multirow[t]{2}{*}{ Nilai } & \multirow{2}{*}{$\begin{array}{c}\text { \% Ketuntasan } \\
\text { Perorangan }\end{array}$} & \multicolumn{2}{|c|}{ Ketuntasan Belajar } & \multirow[t]{2}{*}{ Keterangan } \\
\hline & & & Tuntas & Belum Tuntas & \\
\hline 1 & 75 & $75 \%$ & $\checkmark$ & & $\mathrm{T}$ \\
\hline 2 & 60 & $60 \%$ & & $\checkmark$ & BT \\
\hline 3 & 60 & $60 \%$ & & $\checkmark$ & BT \\
\hline 4 & 70 & $70 \%$ & $\checkmark$ & & $\mathrm{T}$ \\
\hline 5 & 70 & $70 \%$ & $\checkmark$ & & $\mathrm{T}$ \\
\hline 6 & 70 & $70 \%$ & $\checkmark$ & & $\mathrm{T}$ \\
\hline 7 & 65 & $65 \%$ & & $\checkmark$ & BT \\
\hline 8 & 75 & $75 \%$ & $\checkmark$ & & $\mathrm{T}$ \\
\hline 9 & 55 & $55 \%$ & & $\checkmark$ & BT \\
\hline 10 & 70 & $70 \%$ & $\checkmark$ & & $\mathrm{T}$ \\
\hline 11 & 75 & $75 \%$ & $\checkmark$ & & $\mathrm{T}$ \\
\hline 12 & 65 & $65 \%$ & & $\checkmark$ & BT \\
\hline 13 & 55 & $55 \%$ & & $\checkmark$ & BT \\
\hline 14 & 65 & $65 \%$ & & $\checkmark$ & BT \\
\hline 15 & 70 & $70 \%$ & $\checkmark$ & & $\mathrm{T}$ \\
\hline 16 & 70 & $70 \%$ & $\checkmark$ & & $\mathrm{T}$ \\
\hline 17 & 70 & $70 \%$ & $\checkmark$ & & $\mathrm{T}$ \\
\hline 18 & 90 & $90 \%$ & $\checkmark$ & & $\mathrm{T}$ \\
\hline 19 & 75 & $75 \%$ & $\checkmark$ & & $\mathrm{T}$ \\
\hline 20 & 75 & $75 \%$ & $\checkmark$ & & $\mathrm{T}$ \\
\hline 21 & 70 & $70 \%$ & $\checkmark$ & & $\mathrm{T}$ \\
\hline 22 & 60 & $60 \%$ & & $\checkmark$ & BT \\
\hline 23 & 65 & $65 \%$ & & $\checkmark$ & BT \\
\hline 24 & 90 & $90 \%$ & $\checkmark$ & & $\mathrm{T}$ \\
\hline 25 & 60 & $60 \%$ & & $\checkmark$ & BT \\
\hline Jumlah & 1725 & & 15 & 10 & \\
\hline Rata-rata & 69 & & - & & \\
\hline Persen & $69 \%$ & & $60 \%$ & $40 \%$ & \\
\hline
\end{tabular}

Berdasarkan tabel di atas diperoleh gambaran bahwa nilai tertinggi adalah 90 dan nilai terendah 55. Ketuntasan nilai belajar yang diharapkan belum tercapai, persentase ketuntasan yang diperoleh adalah $69 \%$ dari ketuntasan yang ditetapkan yaitu $85 \%$.

\section{Aspek afektif}

Keberhasilan pemahaman konsep siswa dari aspek afektif dilihat selama proses pembelajaran berlangsung selama siklus I. Nilai yang diperoleh siswa dalam aspek afektif dapat dilihat pada tabel berikut:

Tabel 4

Nilai Afektif Siswa

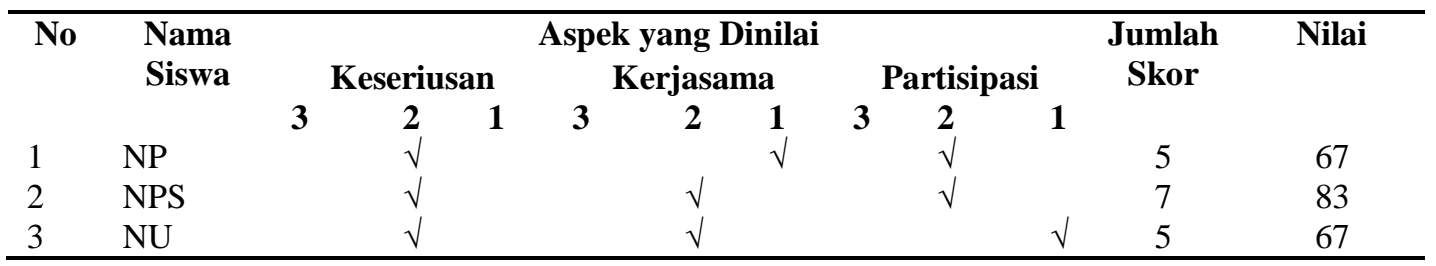

Jurnal Penelitian Pendidikan Indonesia | Akses Online : http://jurnal.iicet.org 


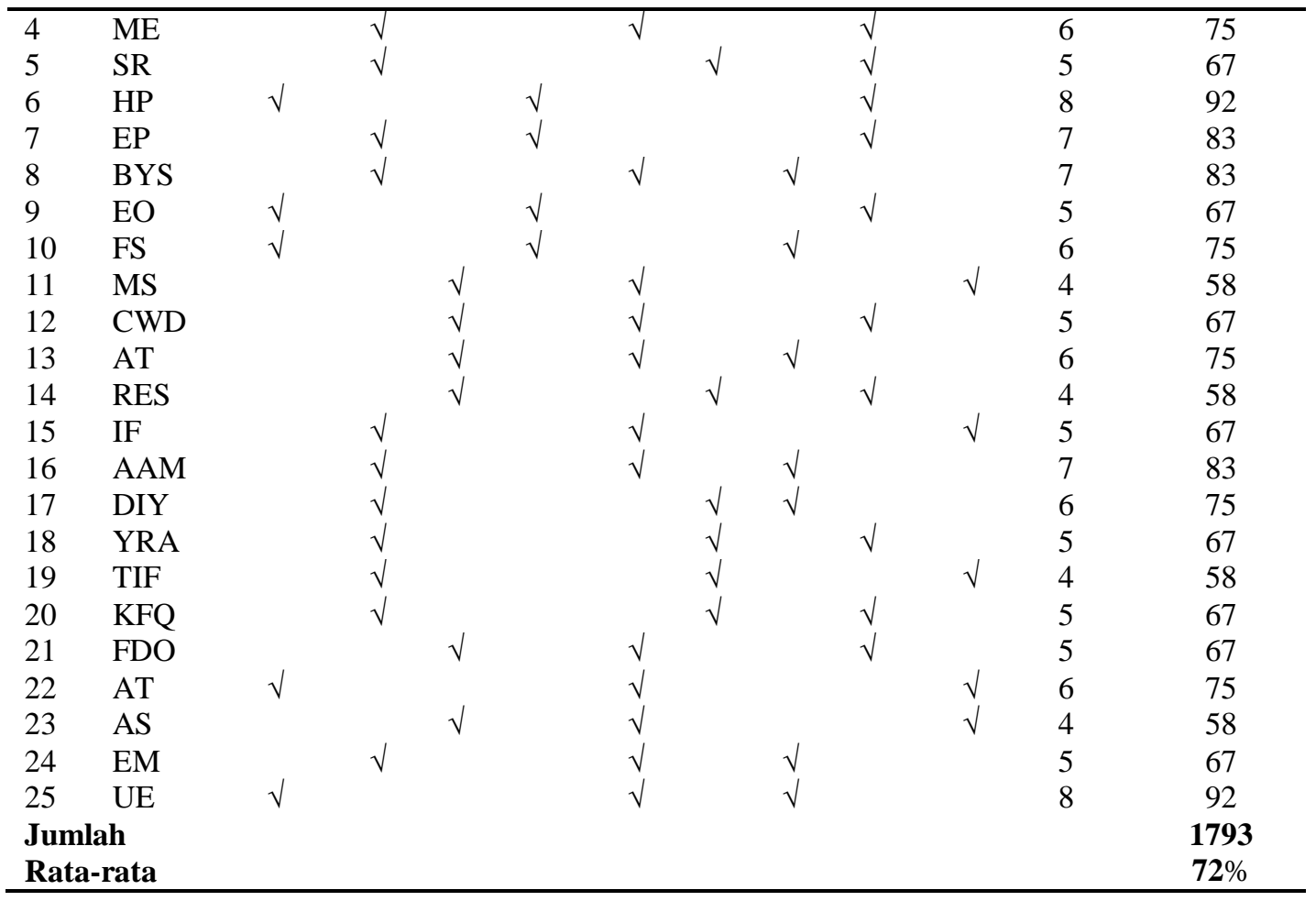

Berdasarkan tabel di atas, dapat diperoleh gambaran bahwa hasil penilaian afektif siswa pada siklus I sebagai berikut: nilai tertinggi adalah 92 dan nilai terendah 58, diperoleh nilai ratarata 72 . Berdasarkan taraf keberhasilan, 72 berada pada taraf cukup.

\section{Aspek Psikomotor}

Keberhasilan pemahaman konsep siswa dari aspek psikomotor dilihat selama proses pembelajaran berlangsung selama siklus I. Nilai yang diperoleh siswa dalam aspek psikomotor dapat dilihat pada tabel berikut:

Tabel 5

Nilai Psikomotor Siswa

\begin{tabular}{|c|c|c|c|c|c|c|c|c|c|c|c|c|}
\hline \multirow[t]{3}{*}{ No } & \multirow[t]{3}{*}{ Nama Siswa } & \multicolumn{9}{|c|}{ Aspek yang Dinilai } & \multirow{3}{*}{$\begin{array}{c}\text { Jumlah } \\
\text { Skor }\end{array}$} & \multirow[t]{3}{*}{ Nilai } \\
\hline & & \multicolumn{3}{|c|}{$\begin{array}{c}\text { Ketepatan } \\
\text { Langkah } \\
\text { Kerja }\end{array}$} & \multicolumn{3}{|c|}{$\begin{array}{c}\text { Keterampilan } \\
\text { Menggunakan } \\
\text { Alat }\end{array}$} & \multicolumn{3}{|c|}{$\begin{array}{c}\text { Presentasi } \\
\text { Kerja }\end{array}$} & & \\
\hline & & 3 & 2 & 1 & 3 & 2 & 1 & 3 & 2 & 1 & & \\
\hline 1 & NP & & & $\sqrt{ }$ & $\sqrt{ }$ & & & & $\sqrt{ }$ & & 6 & 75 \\
\hline 2 & NPS & & $\sqrt{ }$ & & & $\sqrt{ }$ & & & $\sqrt{ }$ & & 6 & 75 \\
\hline 3 & NU & & & $\sqrt{ }$ & & & $\sqrt{ }$ & & $\sqrt{ }$ & & 4 & 58 \\
\hline 4 & $\mathrm{ME}$ & & $\sqrt{ }$ & & & $\sqrt{ }$ & & & & $\sqrt{ }$ & 5 & 67 \\
\hline 5 & SR & & & $\sqrt{ }$ & & & $\sqrt{ }$ & & $\sqrt{ }$ & & 4 & 58 \\
\hline 6 & $\mathrm{HP}$ & $\sqrt{ }$ & & & & $\sqrt{ }$ & & & $\sqrt{ }$ & & 7 & 83 \\
\hline 7 & EP & & $\sqrt{ }$ & & & $\sqrt{ }$ & & $\sqrt{ }$ & & & 7 & 83 \\
\hline 8 & BYS & & $\sqrt{ }$ & & $\sqrt{ }$ & & & $\sqrt{ }$ & & & 8 & 92 \\
\hline 9 & $\mathrm{EO}$ & & $\sqrt{ }$ & & & $\sqrt{ }$ & & & $\sqrt{ }$ & & 6 & 75 \\
\hline 10 & FS & $\sqrt{ }$ & & & & $\sqrt{ }$ & & & $\sqrt{ }$ & & 7 & 83 \\
\hline 11 & MS & $\sqrt{ }$ & & & & & $\sqrt{ }$ & & $\sqrt{ }$ & & 6 & 75 \\
\hline 12 & CWD & & $\sqrt{ }$ & & & & $\sqrt{ }$ & & $\sqrt{ }$ & & 5 & 67 \\
\hline
\end{tabular}

Jurnal Penelitian Pendidikan Indonesia | Akses Online : http://jurnal.iicet.org 


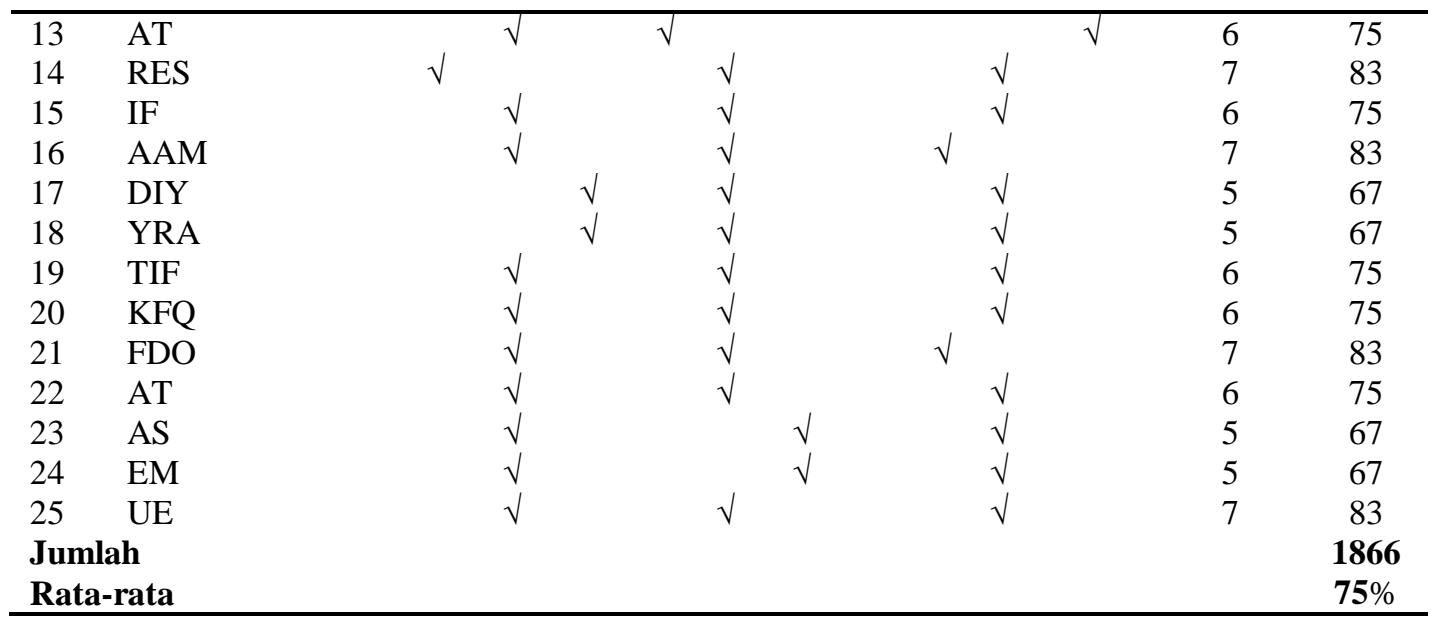

Berdasarkan tabel di atas, dapat diperoleh gambaran bahwa penilaian psikomotor sebagai berikut: nilai tertinggi adalah 92 dan nilai terendah 58 dengan rata-rata 75\%. Berdasarkan taraf keberhasilan, $75 \%$ berada pada taraf cukup untuk pemahaman konsep pada aspek psikomotor.

\section{Refleksi}

Berdasarkan refleksi/diskusi yang dilakukan antara guru dan pengamatan, ditemukan beberapa kekurangan pada siklus I yaitu sebagai berikut:

1. Pada saat guru mengajukan pertanyaan, siswa kurang dapat memahaminya karena bahasa yang digunakan cukup sulit.

2. Pada proses pembelajaran, sebagian kecil siswa yang berani bertanya atau mengemukakan pendapat karena kurangnya motivasi dari guru.

3. Pada saat melakukan percobaan, siswa banyak yang tidak serius atau bermain-main, untuk itu perlu perhatian dan bimbingan dari guru.

4. Guru tidak memberikan kesempatan kepada siswa untuk bertanya setelah belajar kelompok. Guru langsung saja menuntun siswa untuk menyimpulkan pelajaran.

5. Guru tidak membahas atau mengoreksi hasil latihan siswa secara bersama-sama. Hal ini perlu dilakukan agar siswa mengetahui dan paham di mana kesalahannya dan melatih kejujuran siswa dalam memeriksa.

\section{Siklus II}

\section{Perencanaan}

Hasil refleksi pada siklus 1 menunjukan subjek penelitian belum mencapai standar keberhasilan yang di harapkan. Pembelajaran siklus II diharapkan dapat terjadi perubahan pada beberapa aspek yang diamati antara lain: a) Siswa pada aspek afektif diharapkan memiliki perhatian terhadap pelajaran, kemampuan dalam komunikasi, ikut berperan aktif dalam kelompok, serta berani mengemukakan pendapat. b) Pada aspek psikomotor siswa diharapkan dapat melakukan kerja sama dalam kelompok serta terampil dalam menggunakan alat/media pembelajaran. c) Pada aspek kognitif diharapkan terjadi peningkatan hasil belajar.

Indikator pembelajaran adalah (1) menyebutkan berbagai jenis pesawat sederhana misalnya tuas, bidang miring, roda dan katrol. (2) mengidentifikasi prinsip bidang miring. (3) mengidentifikasi prinsip kerja roda. (4) menyebutkan contoh kegiatan manusia yang menggunakan pesawat sederhana jenis bidang miring dan roda. Rencana pembelajaran selain memuat indikator juga memuat materi pembelajaran, materi pokok, metode. 


\section{Pelaksanaan}

Pada kegiatan awal, guru mengucapkan salam kemudian menyampaikan topik yang akan dipelajari yaitu pesawat sederhana jenis bidang miring dan roda dengan menggunakan metode eksperimen. Setelah itu guru menyampaikan tujuan yang ingin dicapai. Guru membuka pelajaran dengan mengajukan pertanyaan: Apakah anak-anak pernah melihat jalan yang berliku/ mendaki?

Pembelajaran dilanjutkan dengan kegiatan inti. Guru mengajukan pertanyaan tentang pesawat sederhana yang digunakan dalam memindahkan drum ke atas mobil. Proses pembelajaran dilaksanakan dengan menggunakan metode eksperimen. Siswa bersemangat dalam merespon dan menjawab pertanyaan guru dengan benar. Siswa duduk dalam kelompok yang sudah terbentuk sebelumnya. Guru membagi LKS 4 dan berbagai alat serta bahan pelajaran kepada masing-masing kelompok. Siswa mengamati alat yang sudah dibagikan. Guru membimbing siswa melakukan ekperimen sesuai dengan LKS 4 untuk membuktikan bahwa bidang miring dapat memudahkan pekerjaan. Guru mengamati kelompok yang mengalami kesulitan melakukan percobaan dan memahami materi. Setelah melakukan percobaan, guru meminta siswa mengumpulkan alat percobaan. Kemudian siswa diminta melaporkan hasil percobaan dan diskusinya ke depan kelas. Secara serempak masing-masing kelompok dengan berani menunjuk tangannya untuk membacakan hasil percobaannya ke depan kelas.

Guru menunjuk kelompok 1 untuk melaporkan hasil percobannya ke depan kelas. Guru meminta kelompok lain untuk menanggapinya, semua kelompok menunjuk tangan untuk menanggapi laporan dari kelompok 1. Guru meminta satu persatu dari masing-masing kelompok untuk menyampaikan tanggapannya dan ternyata jawaban dari masing-masing kelompok tentang panjang rentang karet berbeda. Untuk menyikapi hal itu, guru menjelaskan bahwa perbedaan panjang karet itu tidak apa-apa dikarenakan perbedaan dari gelang karetnya. Guru menekankan bahwa yang terpenting adalah panjang karet pada percobaan satu sampai tiga makin berkurang, yang disebabkan karena bidangnya semakin miring. Kemudian guru memberikan penguatan dan hadiah bagi wakil kelompok yang membacakan laporannya ke depan kelas. Mereka juga diajarkan untuk saling bertanya jawab tentang percobaan tersebut.

Guru membagikan LKS 5 dan bahan untuk percobaan kepada masing-masing kelompok, perwakilan masing-masing kelompok mengambilnya ke depan kelas. Guru meminta siswa untuk memahami LKS 5 dan memberikan kesempatan kepada siswa untuk bertanya. Guru meminta siswa melakukan percobaan dikelompoknya masing-masing. Guru memantau dan membimbing siswa dalam melakukan kerja kelompok. Siswa telah terlihat dapat bekerjasama dengan baik dalam kelompok dan aktif dalam mengeluarkan pendapatnya. Setelah selesai melakukan percobaan, guru meminta salah satu kelompok yang bersedia untuk membacakan hasil percobaannya ke depan kelas. Secara serempak masing-masing kelompok dengan spontan menunjuk tangannya agar ditunjuk guru untuk membacakan hasil percobaannya ke depan kelas.

Guru menunjuk kelompok 5 untuk melaporkan hasil percobaannya ke depan kelas dan meminta kelompok lain untuk menanggapinya. Dengan serempak semua kelompok mengatakan bahwa hasil percobaan mereka sama. Ternyata siswa dapat melakukan percobaan dengan hasil yang baik. Guru memberikan penguatan dan hadiah kepada wakil kelompok yang telah maju ke depan kelas untuk membacakan laporannya. Guru meminta siswa mengumpulkan LKSnya ke depan kelas. Mereka juga diajarkan untuk saling bertanya jawab tentang percobaan tersebut dibawah bimbingan.

Pelaksanaan Kegiatan akhir dengan cara guru meminta siswa untuk duduk di kursinya masing-masing. Kemudian guru memberi kesempatan kepada siswa untuk bertanya tentang materi yang belum dipahaminya. Namun tidak ada siswa yang bertanya. Selanjutnnya guru melakukan tanya jawab dengan siswa untuk membimbing mereka menyimpulkan pelajaran. Guru melakukan evaluasi/latihan dan memberikan soal latihan kepada masing-masing siswa. 
Guru mengingatkan bahwa siswa tidak boleh bekerja sama serta mengerjakan soal sendirisendiri.

\section{Pengamatan}

Hasil observasi dari aspek guru dan siswa selama mengikuti proses pembelajaran sebagai berikut. Karakteristik guru selama metode eksperimen dilaksanakan dapat dilihat pada tabel 6 berikut ini.

Tabel 6

Analisis Karakteristik Guru dalam Menerapkan Metode Eksperimen

\begin{tabular}{|c|c|c|c|c|c|c|}
\hline \multirow{2}{*}{$\begin{array}{c}\text { Kegiatan } \\
\text { pembelajaran }\end{array}$} & \multirow[t]{2}{*}{ Karakteristik } & & \multirow[t]{2}{*}{ Deskriptor } & \multicolumn{3}{|c|}{ Kualifikasi } \\
\hline & & & & SB & $\mathrm{B}$ & $\mathrm{C}$ \\
\hline & & & & 3 & 2 & 1 \\
\hline \multirow[t]{9}{*}{ Kegiatan awal } & $\begin{array}{l}\text { Mempersiapkan } \\
\text { kondisi kelas }\end{array}$ & 1 & $\begin{array}{l}\text { Mempersiapkan media, alat, dan } \\
\text { sumber belajar }\end{array}$ & $\sqrt{ }$ & & \\
\hline & & 2 & Merapikan tempat duduk siswa & & & \\
\hline & & 3 & $\begin{array}{l}\text { Mengambil absen siswa } \\
\text { sebelum pembelajaran }\end{array}$ & & & \\
\hline & $\begin{array}{l}\text { Membuka skemata } \\
\text { siswa melalui }\end{array}$ & 1 & $\begin{array}{l}\text { Membuka skemata sesuai } \\
\text { dengan materi pembelajaran }\end{array}$ & $\sqrt{ }$ & & \\
\hline & pertanyaan & 2 & $\begin{array}{l}\text { Menggunakan kalimat tanya } \\
\text { yang mudah dimengerti siswa. }\end{array}$ & & & \\
\hline & & 3 & $\begin{array}{l}\text { Tidak menimbulkan jawaban } \\
\text { yang serempak. }\end{array}$ & & & \\
\hline & Menjelaskan bahwa & 1 & Arahan yang diberikan jelas & $\sqrt{ }$ & & \\
\hline & $\begin{array}{l}\text { jalan yang mendaki } \\
\text { berbentuk berliku-liku }\end{array}$ & 2 & $\begin{array}{l}\text { Penjelasan dapat diterima oleh } \\
\text { semua siswa }\end{array}$ & & & \\
\hline & $\begin{array}{l}\text { menggunakan prinsip } \\
\text { kerja bidang miring. }\end{array}$ & 3 & $\begin{array}{l}\text { Kalimat yang digunakan mudah } \\
\text { dipahami siswa }\end{array}$ & & & \\
\hline \multirow[t]{9}{*}{ Kegiatan inti } & $\begin{array}{l}\text { Membagi siswa ke } \\
\text { dalam beberapa } \\
\text { kelompok }\end{array}$ & 1 & $\begin{array}{l}\text { Kelompok dibentuk berdasarkan } \\
\text { rentang intelektual yang } \\
\text { beragam. }\end{array}$ & & $\sqrt{ }$ & \\
\hline & & 2 & $\begin{array}{l}\text { Kelompok dibentuk berdasarkan } \\
\text { jenis kelamin yang berbeda }\end{array}$ & & & \\
\hline & & 3 & $\begin{array}{l}\text { Mengorganisasikan fasilitas } \\
\text { yang dibutuhkan dalam kerja } \\
\text { kelompok }\end{array}$ & & & \\
\hline & $\begin{array}{l}\text { Membagikan alat dan } \\
\text { bahan untuk melakukan } \\
\text { eksprimen }\end{array}$ & 1 & $\begin{array}{l}\text { Memberikan alat dan bahan } \\
\text { yang sama pada setiap } \\
\text { kelompok sesuai perencanaan. }\end{array}$ & $\sqrt{ }$ & & \\
\hline & & 2 & $\begin{array}{l}\text { Memberikan alat dan bahan } \\
\text { dengan jumlah yang sama untuk } \\
\text { semua kelompok }\end{array}$ & & & \\
\hline & & 3 & $\begin{array}{l}\text { Alat dan bahan yang diberikan } \\
\text { mudah digunakan siswa }\end{array}$ & & & \\
\hline & $\begin{array}{l}\text { Menugaskan siswa } \\
\text { melakukan eksprimen }\end{array}$ & 1 & $\begin{array}{l}\text { Memberikan bimbingan pada } \\
\text { siswa dalam melakukan } \\
\text { percobaan. }\end{array}$ & $\sqrt{ }$ & & \\
\hline & & 2 & $\begin{array}{l}\text { Menyediakan LKS sebagai } \\
\text { panduan kerja kelompok. }\end{array}$ & & & \\
\hline & & 3 & Memberikan kesempatan & & & \\
\hline
\end{tabular}

Jurnal Penelitian Pendidikan Indonesia | Akses Online : http://jurnal.iicet.org 


\begin{tabular}{|c|c|c|c|c|c|}
\hline & & & $\begin{array}{l}\text { kepada siswa utuk menanyakan } \\
\text { langkah percobaan yang kurang } \\
\text { dipahami. }\end{array}$ & & \\
\hline & $\begin{array}{l}\text { Mengarahkan siswa } \\
\text { dalam melakukan }\end{array}$ & 1 & $\begin{array}{l}\text { Memantau siswa dalam } \\
\text { melakukan eksperimen. }\end{array}$ & & $\sqrt{ }$ \\
\hline & eksprimen & 2 & $\begin{array}{l}\text { Menjelaskan cara melakukan } \\
\text { eksperimen. }\end{array}$ & & \\
\hline & & 3 & $\begin{array}{l}\text { Memotivasi siswa untuk } \\
\text { melakukan eksperimen. }\end{array}$ & & \\
\hline & $\begin{array}{l}\text { Membimbing siswa } \\
\text { mengidentifikasi tuas }\end{array}$ & 1 & $\begin{array}{l}\text { Memberikan pertanyaan yang } \\
\text { sesuai dengan mengidentifikasi } \\
\text { tuas. }\end{array}$ & $\sqrt{ }$ & \\
\hline & & 2 & $\begin{array}{l}\text { Membimbing siswa dalam } \\
\text { mengidentifikasi prinsip kerja } \\
\text { bidang miring dan roda. }\end{array}$ & & \\
\hline & & 3 & $\begin{array}{l}\text { Merespon kesulitan siswa yang } \\
\text { mengalami kesulitan dalam } \\
\text { mengidentifikasi tuas. prinsip } \\
\text { kerja bidang miring dan roda. }\end{array}$ & & \\
\hline & $\begin{array}{l}\text { Mengarahkan siswa } \\
\text { dalam menyimpulkan }\end{array}$ & 1 & $\begin{array}{l}\text { Mengajukan pertanyaan sesui } \\
\text { dengan materi yang dipelajari. }\end{array}$ & $\sqrt{ }$ & \\
\hline & pembelajaran & 2 & Memberikan kesempatan & & \\
\hline & & & $\begin{array}{l}\text { kepada siswa untuk dapat } \\
\text { mengungkapkan pengetahuan } \\
\text { yang telah dipelajarinya. }\end{array}$ & & \\
\hline & & 3 & $\begin{array}{l}\text { Memberikan kesempatan untuk } \\
\text { mencatat konsep yang } \\
\text { dipelajari. }\end{array}$ & & \\
\hline \multirow[t]{7}{*}{ Kegiatan akhir } & $\begin{array}{l}\text { Memberi evaluasi pada } \\
\text { siswa }\end{array}$ & 1 & $\begin{array}{l}\text { Soal sesuai dengan materi yang } \\
\text { diajarkan }\end{array}$ & $\sqrt{ }$ & \\
\hline & & 2 & $\begin{array}{l}\text { Sesuai dengan tingkat } \\
\text { kemampuan siswa }\end{array}$ & & \\
\hline & & 3 & $\begin{array}{l}\text { Soal mudah dipahami oleh } \\
\text { siswa }\end{array}$ & & \\
\hline & $\begin{array}{l}\text { Memantau siswa dalam } \\
\text { menyelesaikan evaluasi }\end{array}$ & 1 & $\begin{array}{l}\text { Mengkordinir siswa dalam } \\
\text { menyelesaikan evaluasi. }\end{array}$ & & $\sqrt{ }$ \\
\hline & tersebut & 2 & $\begin{array}{l}\text { Memberikan arahan kepada } \\
\text { siswa dalam menyelesaikan } \\
\text { evaluasi }\end{array}$ & & \\
\hline & & 3 & $\begin{array}{l}\text { Mengumpulkan evalusi yang } \\
\text { dikerjakan siswa }\end{array}$ & & \\
\hline & & & & 24 & 6 \\
\hline Jumlah & & & & 30 & \\
\hline
\end{tabular}

Dari tabel diatas dapat dilihat bahwa karakteristik guru telah dilaksanakan dalam pembelajaran menggunakan metode eksperimen. Siklus II sudah memperoleh hasil yang memuaskan terhadap karakteristik guru dalam melaksanakan pembelajaran.

Pengamatan terhadap karakteristik siswa dalam melaksanakan metode eksperimen sudah cukup baik. Hal ini terlihat pada siswa menanggapi pertanyaan yang diberikan oleh guru dengan baik. Siswa sangat antusias untuk melakukan percobaan yang belum pernah dilakukannya. Siswa sudah bisa berdiskusi dalam belajar sehingga diskusi terlaksana dengan baik. 
Tabel 7

\section{Analisis Karakteristik Siswa dalam Menerapkan Metode Eksperimen}

\begin{tabular}{|c|c|c|c|c|c|}
\hline \multirow{3}{*}{$\begin{array}{c}\text { Kegiatan } \\
\text { pembelajaran }\end{array}$} & \multirow[t]{3}{*}{ Karakteristik } & \multirow[t]{3}{*}{ Deskriptor } & \multicolumn{3}{|c|}{ Kualifikasi } \\
\hline & & & SB & $\mathrm{B}$ & $\mathrm{C}$ \\
\hline & & & 3 & 2 & 1 \\
\hline \multirow[t]{27}{*}{ Kegiatan awal } & Mempersiapkan & Mempersiapkan sumber belajar & $\sqrt{ }$ & & \\
\hline & kondisi kelas & 2. Duduk dengan rapi & & & \\
\hline & & $\begin{array}{l}\text { 3. Mendengarkan absen sebelum } \\
\text { pembelajaran }\end{array}$ & & & \\
\hline & Membuka skemata & 1. Mendengarkan pertanyaan guru & $\sqrt{ }$ & & \\
\hline & siswa melalui & 2. Menjawab pertanyaan guru. & & & \\
\hline & pertanyaan & $\begin{array}{l}\text { 3. Tidak menimbulkan jawaban } \\
\text { yang serempak. }\end{array}$ & & & \\
\hline & Menyimak & 1. Menyimak penjelasan guru. & & $\sqrt{ }$ & \\
\hline & penjelasan guru & $\begin{array}{l}\text { 2. Menanyakan hal-hal yang } \\
\text { kurang dipahami. }\end{array}$ & & & \\
\hline & miring dan roda. & 3. Menyebutkan contoh lain dari & & & \\
\hline & $\begin{array}{l}\text { Duduk beberapa } \\
\text { kelompok }\end{array}$ & $\begin{array}{l}\text { pesawat sederhana } \\
\text { 1. Mengorganisasi anggota } \\
\text { kelompok dengan dengan tertip. }\end{array}$ & $\sqrt{ }$ & & \\
\hline & & $\begin{array}{l}\text { 2. Mau menerima anggota } \\
\text { kelompoknya. }\end{array}$ & & & \\
\hline & & $\begin{array}{l}\text { 3. Saling berinteraksi antar anggota } \\
\text { kelompok. }\end{array}$ & & & \\
\hline & $\begin{array}{l}\text { Menerima alat dan } \\
\text { bahan untuk }\end{array}$ & $\begin{array}{l}\text { 1. Mengambil alat eksperimen } \\
\text { dengan tertib. }\end{array}$ & $\sqrt{ }$ & & \\
\hline & $\begin{array}{l}\text { melakukan } \\
\text { eksprimen beserta }\end{array}$ & $\begin{array}{l}\text { 2. Menggunakan alat eksperimen } \\
\text { dengan baik. }\end{array}$ & & & \\
\hline & LKS & $\begin{array}{l}\text { 3. Memposisikan alat eksperimen } \\
\text { dengan baik. }\end{array}$ & & & \\
\hline & $\begin{array}{l}\text { Melakukan } \\
\text { eksprimen }\end{array}$ & $\begin{array}{l}\text { 1. Melakukan eksperimen sesuai } \\
\text { dengan langkah-langkah } \\
\text { eksperimen. }\end{array}$ & & $\sqrt{ }$ & \\
\hline & & $\begin{array}{l}\text { 2. Saling bekerja sama dalam } \\
\text { melakukan eksperimen. }\end{array}$ & & & \\
\hline & & $\begin{array}{l}\text { 3. Melakukan eksperimen dengan } \\
\text { serius dan teliti. }\end{array}$ & & & \\
\hline & $\begin{array}{l}\text { Melaporkan hasil } \\
\text { eksperimen. }\end{array}$ & $\begin{array}{l}\text { 1. Mengamati eksperimen dengan } \\
\text { cermat. }\end{array}$ & $\sqrt{ }$ & & \\
\hline & & $\begin{array}{l}\text { 2. Mendiakusikan alat ekperimen } \\
\text { dalam kelompok. }\end{array}$ & & & \\
\hline & & $\begin{array}{l}\text { 3. Mencatat hasil ekperimen dalam } \\
\text { LKS. }\end{array}$ & & & \\
\hline & $\begin{array}{l}\text { Membimbing siswa } \\
\text { mengidentifikasi } \\
\text { prinsip kerja }\end{array}$ & $\begin{array}{l}\text { 1. Mengidentifikasi jenis-jenis } \\
\text { bidang miring dan roda } \\
\text { berdasarkan eksperimen. }\end{array}$ & $\sqrt{ }$ & & \\
\hline & $\begin{array}{l}\text { bidang miring dan } \\
\text { roda. }\end{array}$ & $\begin{array}{l}\text { 2. Mengidentifikasi mamfaat } \\
\text { bidang miring dan roda } \\
\text { berdasarkan eksperimen }\end{array}$ & & & \\
\hline & & 3. Mengidentifikasi penggunaan & & & \\
\hline & & bidang miring dan roda dalam & & & \\
\hline & & kehidupan kehidupan sehari- & & & \\
\hline & & hari. & & & \\
\hline
\end{tabular}

Jurnal Penelitian Pendidikan Indonesia | Akses Online : http://jurnal.iicet.org 


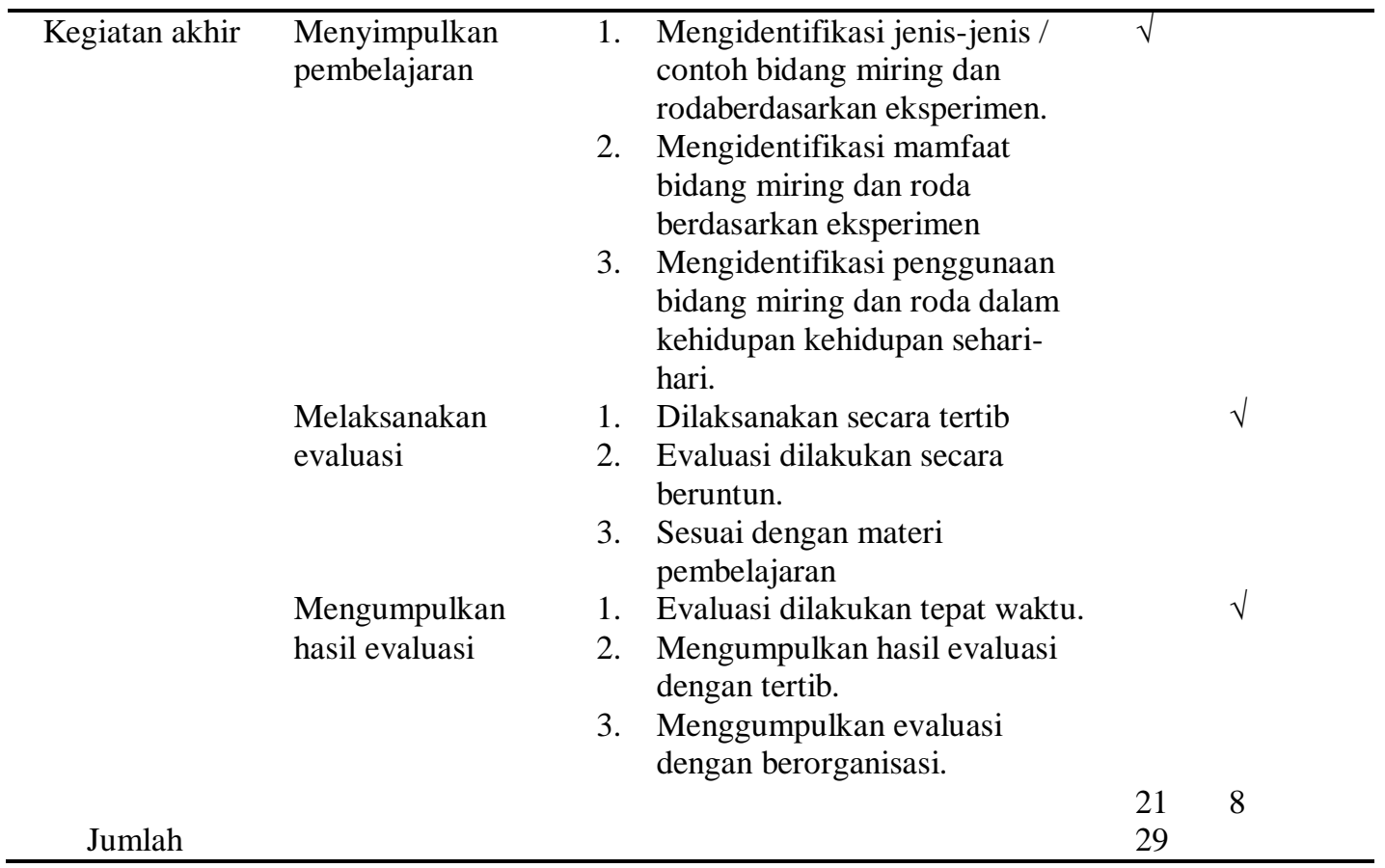

Dari tabel di atas dapat dilihat bahwa siswa sudah melaksanakan karakteristik pembelajaran menggunakan metode eksperimen sebanyak 21 buah dengan sangat baik. Hal ini menunjukkan bahwa siklus II sudah memperoleh hasil yang memuaskan. Keberhasilan yang diharapkan sudah lebih dari $70 \%$.

Keberhasilan siswa dalam pembelajaran pesawat sederhana melalui metode eksperimen dapat dilihat dari hasil evaluasi/latihan yang dicapai pada siklus II.

\section{Tabel 8}

\begin{tabular}{|c|c|c|c|c|c|}
\hline \multirow[t]{2}{*}{ No } & \multirow[t]{2}{*}{ Nilai } & \multirow{2}{*}{$\begin{array}{c}\% \text { Ketuntasan } \\
\text { Perorangan }\end{array}$} & \multicolumn{2}{|c|}{ Ketuntasan Belajar } & \multirow[t]{2}{*}{ Keterangan } \\
\hline & & & Tuntas & Belum Tuntas & \\
\hline 1 & 80 & $80 \%$ & $\checkmark$ & - & $\mathrm{T}$ \\
\hline 2 & 85 & $85 \%$ & $\checkmark$ & - & $\mathrm{T}$ \\
\hline 3 & 80 & $80 \%$ & $\checkmark$ & - & $\mathrm{T}$ \\
\hline 4 & 65 & $65 \%$ & - & $\checkmark$ & $\mathrm{BT}$ \\
\hline 5 & 95 & $95 \%$ & $\checkmark$ & - & $\mathrm{T}$ \\
\hline 6 & 85 & $85 \%$ & $\checkmark$ & - & $\mathrm{T}$ \\
\hline 7 & 80 & $70 \%$ & $\checkmark$ & - & $\mathrm{T}$ \\
\hline 8 & 80 & $80 \%$ & $\checkmark$ & - & $\mathrm{T}$ \\
\hline 9 & 75 & $75 \%$ & $\checkmark$ & - & $\mathrm{T}$ \\
\hline 10 & 90 & $90 \%$ & $\checkmark$ & - & $\mathrm{T}$ \\
\hline 11 & 75 & $75 \%$ & $\checkmark$ & - & $\mathrm{T}$ \\
\hline 12 & 100 & $100 \%$ & $\checkmark$ & - & $\mathrm{T}$ \\
\hline 13 & 70 & $70 \%$ & $\checkmark$ & - & $\mathrm{T}$ \\
\hline 14 & 80 & $80 \%$ & $\checkmark$ & - & $\mathrm{T}$ \\
\hline 15 & 85 & $85 \%$ & $\checkmark$ & - & $\mathrm{T}$ \\
\hline
\end{tabular}

Jurnal Penelitian Pendidikan Indonesia | Akses Online : http://jurnal.iicet.org 


\begin{tabular}{cllccc}
\hline 16 & 70 & $70 \%$ & $\checkmark$ & - & $\mathrm{T}$ \\
17 & 95 & $95 \%$ & $\checkmark$ & - & $\mathrm{T}$ \\
18 & 75 & $75 \%$ & $\checkmark$ & - & $\mathrm{T}$ \\
19 & 85 & $85 \%$ & $\checkmark$ & - & $\mathrm{T}$ \\
20 & 75 & $75 \%$ & $\checkmark$ & - & $\mathrm{T}$ \\
21 & 80 & $80 \%$ & $\checkmark$ & - & $\mathrm{T}$ \\
22 & 75 & $75 \%$ & $\checkmark$ & - & $\mathrm{T}$ \\
23 & 85 & $85 \%$ & $\checkmark$ & - & $\mathrm{T}$ \\
24 & 80 & $80 \%$ & $\checkmark$ & - & $\mathrm{T}$ \\
25 & 100 & $100 \%$ & $\checkmark$ & - & $\mathrm{T}$ \\
Jumlah & 2045 & & 24 & 1 & \\
Rata-rata & 81,8 & & - & - & \\
Persen & $82 \%$ & & $96 \%$ & $1 \%$ & \\
\hline
\end{tabular}

Ketuntasan Hasil Belajar Siswa

Berdasarkan tabel di atas diperoleh gambaran bahwa nilai tertinggi adalah 100 dan nilai terendah 65. Ketuntasan nilai belajar yang diharapkan sudah mencapai target, di mana persentase ketuntasan yang diperoleh adalah $96 \%$ dari ketuntasan yang ditetapkan yaitu $85 \%$. Dari nilai yang diperoleh siswa, dapat disimpulkan bahwa pemahaman konsep pembelajaran pada siklus II ini sudah terlaksana dengan baik dan sesuai dengan yang diharapkan.

Keberhasilan siswa dari aspek afektif dilihat selama proses pembelajaran berlangsung pada siklus II. Nilai yang diperoleh siswa dalam aspek afektif dapat dilihat pada tabel berikut:

Tabel 9

Nilai Afektif Siswa Siklus II

\begin{tabular}{|c|c|c|c|c|c|c|c|c|c|c|c|c|}
\hline \multirow[t]{3}{*}{ No } & \multirow{3}{*}{$\begin{array}{l}\text { Nama } \\
\text { Siswa }\end{array}$} & \multicolumn{9}{|c|}{ Aspek yang Dinilai } & \multirow{3}{*}{$\begin{array}{c}\text { Jumlah } \\
\text { Skor }\end{array}$} & \multirow[t]{3}{*}{ Nilai } \\
\hline & & \multicolumn{3}{|c|}{ Keseriusan } & \multicolumn{3}{|c|}{ Kerjasama } & \multicolumn{3}{|c|}{ Partisipasi } & & \\
\hline & & 3 & 2 & 1 & 3 & 2 & 1 & 3 & 2 & 1 & & \\
\hline 1 & NP & & $\sqrt{ }$ & & $\sqrt{ }$ & & & & $\sqrt{ }$ & & 7 & 83 \\
\hline 2 & NPS & & $\sqrt{ }$ & & $\sqrt{ }$ & & & $\sqrt{ }$ & & & 8 & 92 \\
\hline 3 & NU & & $\sqrt{ }$ & & & $\sqrt{ }$ & & & $\sqrt{ }$ & & 6 & 75 \\
\hline 4 & ME & & $\sqrt{ }$ & & & $\sqrt{ }$ & & & $\sqrt{ }$ & & 6 & 75 \\
\hline 5 & SR & & $\sqrt{ }$ & & & $\sqrt{ }$ & & & $\sqrt{ }$ & & 6 & 75 \\
\hline 6 & HP & & $\sqrt{ }$ & & $\sqrt{ }$ & & & $\sqrt{ }$ & & & 9 & 100 \\
\hline 7 & EP & $\sqrt{ }$ & & & $\sqrt{ }$ & & & & $\sqrt{ }$ & & 8 & 92 \\
\hline 8 & BYS & $\sqrt{ }$ & & & $\sqrt{ }$ & & & & $\sqrt{ }$ & & 8 & 92 \\
\hline 9 & EO & & $\sqrt{ }$ & & & $\sqrt{ }$ & & & $\sqrt{ }$ & & 6 & 75 \\
\hline 10 & FS & & $\sqrt{ }$ & & & $\sqrt{ }$ & & & $\sqrt{ }$ & & 6 & 75 \\
\hline 11 & MS & & & $\sqrt{ }$ & & & $\sqrt{ }$ & & $\sqrt{ }$ & & 5 & 67 \\
\hline 12 & CWD & & $\sqrt{ }$ & & $\sqrt{ }$ & & & & $\sqrt{ }$ & & 7 & 83 \\
\hline 13 & AT & $\sqrt{ }$ & & & & $\sqrt{ }$ & & & $\sqrt{ }$ & & 7 & 83 \\
\hline 14 & RES & & $\sqrt{ }$ & & & $\sqrt{ }$ & & & $\sqrt{ }$ & & 6 & 75 \\
\hline 15 & IF & & $\sqrt{ }$ & & & $\sqrt{ }$ & & & $\sqrt{ }$ & & 6 & 75 \\
\hline 16 & AAM & $\sqrt{ }$ & & & $\sqrt{ }$ & & & $\sqrt{ }$ & & & 9 & 100 \\
\hline 17 & DIY & & $\sqrt{ }$ & & $\sqrt{ }$ & & & $\sqrt{ }$ & & & 8 & 92 \\
\hline 18 & YRA & & $\sqrt{ }$ & & & $\sqrt{ }$ & & & $\sqrt{ }$ & & 6 & 75 \\
\hline 19 & TIF & & $\sqrt{ }$ & & & $\sqrt{ }$ & & & $\sqrt{ }$ & & 6 & 75 \\
\hline 20 & KFQ & & $\sqrt{ }$ & & & $\sqrt{ }$ & & & $\sqrt{ }$ & & 6 & 75 \\
\hline
\end{tabular}

Jurnal Penelitian Pendidikan Indonesia | Akses Online : http://jurnal.iicet.org 


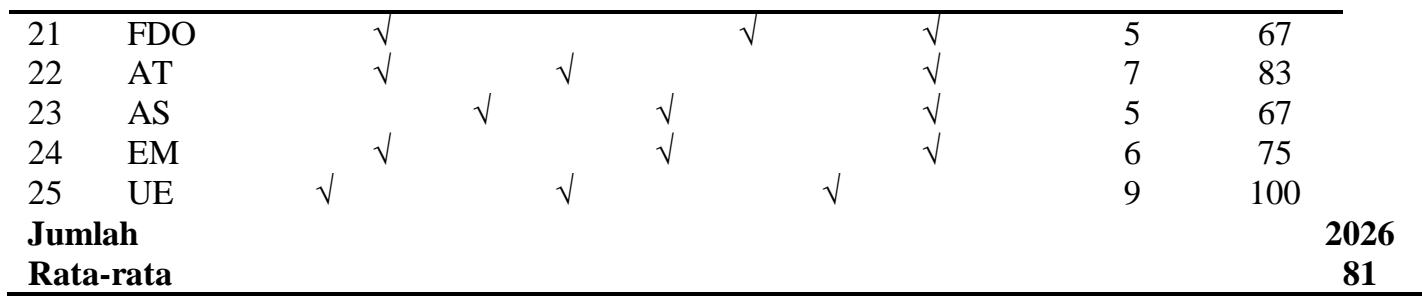

Berdasarkan tabel di atas, dapat diperoleh gambaran bahwa hasil penilaian afektif siswa pada siklus II sebagai berikut: nilai tertinggi adalah 100 dan nilai terendah 67, diperoleh nilai rata-rata 81 . Berdasarkan taraf keberhasilan, $81 \%$ berada pada taraf baik.

Keberhasilan siswa dari aspek psikomotor dilihat selama proses pembelajaran berlangsung pada siklus II. Nilai yang diperoleh siswa dalam aspek psikomotor dapat dilihat pada tabel berikut:

Tabel 10

Nilai Psikomotor Siswa

\begin{tabular}{|c|c|c|c|c|c|c|c|c|c|c|c|c|c|}
\hline \multirow[t]{2}{*}{ No } & \multirow[t]{2}{*}{$\begin{array}{l}\text { Nama } \\
\text { Siswa }\end{array}$} & \multicolumn{3}{|c|}{$\begin{array}{c}\text { Ketepatan } \\
\text { Langkah } \\
\text { Kerja }\end{array}$} & \multicolumn{3}{|c|}{$\begin{array}{c}\text { Aspek yang Dinilai } \\
\text { Keterampilan } \\
\text { Menggunakan } \\
\text { Alat }\end{array}$} & \multicolumn{3}{|c|}{$\begin{array}{c}\text { Presentasi } \\
\text { Kerja }\end{array}$} & \multirow[t]{2}{*}{$\begin{array}{c}\text { Jumlah } \\
\text { Skor }\end{array}$} & \multirow[t]{2}{*}{ Nilai } & \\
\hline & & 3 & 2 & 1 & 3 & 2 & 1 & 3 & 2 & 1 & & & \\
\hline 1 & NP & $\sqrt{ }$ & & & & $\sqrt{ }$ & & & $\sqrt{ }$ & & 7 & 83 & \\
\hline 2 & NPS & & $\sqrt{ }$ & & $\sqrt{ }$ & & & $\sqrt{ }$ & & & 8 & 92 & \\
\hline 3 & NU & & $\sqrt{ }$ & & & $\sqrt{ }$ & & & $\sqrt{ }$ & & 6 & 75 & \\
\hline 4 & $\mathrm{ME}$ & & $\sqrt{ }$ & & & $\sqrt{ }$ & & & $\sqrt{ }$ & & 6 & 75 & \\
\hline 5 & SR & & $\sqrt{ }$ & & & $\sqrt{ }$ & & & $\sqrt{ }$ & & 6 & 75 & \\
\hline 6 & HP & $\sqrt{ }$ & & & $\sqrt{ }$ & & & & $\sqrt{ }$ & & 8 & 92 & \\
\hline 7 & EP & & $\sqrt{ }$ & & & $\sqrt{ }$ & & $\sqrt{ }$ & & & 7 & 83 & \\
\hline 8 & BYS & & $\sqrt{ }$ & & $\sqrt{ }$ & & & $\sqrt{ }$ & & & 8 & 92 & \\
\hline 9 & EO & $\sqrt{ }$ & & & & $\sqrt{ }$ & & $\sqrt{ }$ & & & 8 & 92 & \\
\hline 10 & FS & & $\sqrt{ }$ & & $\sqrt{ }$ & & & $\sqrt{ }$ & & & 8 & 92 & \\
\hline 11 & MS & & $\sqrt{ }$ & & & $\sqrt{ }$ & & & $\sqrt{ }$ & & 6 & 75 & \\
\hline 12 & CWD & $\sqrt{ }$ & & & & $\sqrt{ }$ & & & $\sqrt{ }$ & & 7 & 83 & \\
\hline 13 & AT & $\sqrt{ }$ & & & & $\sqrt{ }$ & & & $\sqrt{ }$ & & 7 & 83 & \\
\hline 14 & RES & & $\sqrt{ }$ & & & $\sqrt{ }$ & & & $\sqrt{ }$ & & 6 & 75 & \\
\hline 15 & IF & & $\sqrt{ }$ & & & $\sqrt{ }$ & & & $\sqrt{ }$ & & 6 & 75 & \\
\hline 16 & AAM & & $\sqrt{ }$ & & $\sqrt{ }$ & & & $\sqrt{ }$ & & & 8 & 92 & \\
\hline 17 & DIY & & $\sqrt{ }$ & & $\sqrt{ }$ & & & $\sqrt{ }$ & & & 8 & 92 & \\
\hline 18 & YRA & & $\sqrt{ }$ & & $\sqrt{ }$ & & & $\sqrt{ }$ & & & 8 & 92 & \\
\hline 19 & TIF & & $\sqrt{ }$ & & $\sqrt{ }$ & & & $\sqrt{ }$ & & & 8 & 92 & \\
\hline 20 & KFQ & & $\sqrt{ }$ & & & $\sqrt{ }$ & & & $\sqrt{ }$ & & 6 & 75 & \\
\hline 21 & FDO & $\sqrt{ }$ & & & & $\sqrt{ }$ & & & $\sqrt{ }$ & & 7 & 83 & \\
\hline 22 & AT & & $\sqrt{ }$ & & & $\sqrt{ }$ & & & $\sqrt{ }$ & & 6 & 75 & \\
\hline 23 & AS & & & $\sqrt{ }$ & & & $\sqrt{ }$ & & $\sqrt{ }$ & & 5 & 67 & \\
\hline 24 & EM & & & $\sqrt{ }$ & & & $\sqrt{ }$ & & $\sqrt{ }$ & & 5 & 67 & \\
\hline 25 & UE & & $\sqrt{ }$ & & $\sqrt{ }$ & & & $\sqrt{ }$ & & & 8 & 92 & \\
\hline \multicolumn{2}{|c|}{ Jumlah } & & & & & & & & & & & & $\begin{array}{c}2069 \\
83\end{array}$ \\
\hline
\end{tabular}


Berdasarkan tabel di atas, dapat diperoleh gambaran bahwa hasil penilaian psikomotor siswa pada siklus II sebagai berikut: nilai tertinggi adalah 92 dan nilai terendah 67, dan nilai rata-rata 83 . Taraf keberhasilan sebesar 83 berada pada taraf baik.

\section{Refleksi}

Hasil pengamatan observer dan kolaborasi setelah proses pembelajaran diperoleh hal-hal sebagai berikut: (1) melalui metode eksperimen ini dapat memotivasi dan mengaktifkan siswa sehingga siswa semakin serius dalam belajar. (2) Melalui kerja kelompok siswa saling kerja sama, tentang bidang miring dan roda. Sebelum melaporkan hasil, siswa memeriksa kebenarannya dalam kelompok masing-masing. Disinilah interaksi antara siswa sangat tampak, apabila interaksi mengalami hambatan guru membimbing dan mengarahkan pekerjaan siswa. Sehingga penguasaan konsep siswa juga lebih baik. (3) Guru sudah mengelola waktu dengan baik dibandingkan siklus I.

Pada akhir siklus II semua siswa yang mendapatkan nilai 70 keatas sesuai dengan standar keberhasilan yang ditetapkan. Sehingga siswa dikatakan tuntas dalam belajar. Pada siklus kedua ini, perencanaan, pelaksanaan, dan hasil belajar sudah semakin menunjukan peningkatan. Mengenai hasil belajar siswa terlihat banyak peningkatan, buktinya pada siklus II ini siswa sudah tuntas semua. Ketuntasan hasil belajar dapat dilihat pada lampiran.

\section{PEMBAHASAN}

Pembahasan didasarkan pada teori yang berkaitan dengan langkah-langkah metode eksperimen, yang terdiri dari beberapa tahap pelaksanaan. Berdasarkan hasil observasi dan diskusi dengan observer rancangan pelaksanaan pembelajaran sudah sesuai dengan langkah-langkah metode eksperimen. Metode eksperimen merupakan suatu format interaksi belajar mengajar yang melibatkan logika induksi untuk menyimpulkan pengamatan terhadap proses dan hasil percobaan yang dilakukan (Moedjiono:1993:77; Udin:1992:219). Pada pelaksanaannya masih kurang sempurna, ini terlihat dari pertanyaan yang diajukan guru masih sulit untuk dipahami siswa. Selain itu, siswa belum terbiasa untuk belajar berkelompok karena terbiasa belajar sendiri-sendiri sehingga mengakibatkan siswa yang berkemampuan rendah menjadi pasif. RPP dirancang berdasarkan langkah-langkah dalam pembelajaran kontekstual. RPP disusun berdasarkan program semester sesuai dengan waktu penelitian, dengan KD menjelaskan pesawat sederhana yang dapat membuat pekerjaan lebih mudah dan lebih cepat, dengan indikatornya mengidentifikasi berbagai jenis pesawat sederhana, mengidentifikasi berbagai jenis tuas/pengungkit berdasarkan golongannya (I, II, dan III), menjelaskan ciri-ciri tuas berdasarkan golongannya masing-masing (I, II dan III), mengidentifikasi kegiatan yang menggunakan tuas/pengungkit, mendemonstrasikan cara kerja pesawat sederhana (tuas/pengungkit).

Pada awal pembelajaran, guru terlebih dahulu mengatur dan menyiapkan siswa untuk mengikuti pelajaran. Karena jadwal pelajaran IPA pada saat itu tidak pada jam pertama pelajaran, maka tidak dilakukan doa bersama. Setelah siswa siap untuk belajar, guru mengabsen siswa dan menyampaikan tujuan belajar agar proses belajar siswa menjadi terarah dan sistematis.

Kegiatan ini dibagi atas beberapa langkah-langkah metode eksperimen kegiatannya sebagai berikut. Guru melakukan pembagian kelompok, kegiatan pembelajaran dilakukan dalam kelompok-kelompok belajar. Guru membentuk 5 kelompok belajar. Masing-masing anggota kelompok terdiri dari 5 orang siswa yang heterogen berdasarkan jenis kelamin dan tingkat kemampuan. Hal ini dilakukan agar siswa dapat saling belajar seperti siswa yang pandai mengajari yang lemah. Hal ini sesuai dengan pendapat Syaiful (dalam Martiningsih, 27:6) bahwa metode eksperimen adalah metode yang memberikan kesempatan kepada siswa baik secara perorangan atau kelompok, untuk dilatih melakukan suatu proses atau percobaan.

Selanjutnya guru meminta siswa untuk melakukan percobaan. Siswa bekerja pada kelompok masing-masing untuk melakukan percobaan sesuai dengan langkah-langkah yang ada dalam LKS. Guru hanya berfungsi sebagai fasilitator. Sebagai fasilitator, guru membimbing dan mengawasi 
jalannya kerja kelompok, sehingga siswa dapat menemukan sendiri pengetahuan yang hendak dimilikinya.

Setelah selesai melakukan percobaan, guru meminta salah satu kelompok yang bersedia untuk membacakan hasil percobaannya ke depan kelas. Secara serempak masing-masing kelompok menunjuk untuk membacakan hasil percobaannya ke depan kelas. Kemudian guru meminta kelompok lain untuk bertanya dan menanggapi hasil percobaan yang telah dilaporkan. Namun tidak terjadi interaksi antar kelompok, sehingga guru melakukan tanya jawab dengan siswa tentang hasil percobaan. Selanjutnya guru melakukan tanya jawab dengan siswa mengenai ciri-ciri tuas/pengungkit berdasarkan percobaan yang telah dilakukan tadi.

Kegiatan akhir, Guru memberikan kesempatan kepada siswa untuk mengingat kembali apa yang telah dipelajari. Guru meminta siswa untuk menyebutkan atau menjelaskan tentang apa-apa saja yang diperolehnya hari itu.Pemahaman konsep siswa pada siklus I belum tuntas karena siswa yang tuntas baru $60 \%$. Sedangkan target yang ingin dicapai yaitu $85 \%$. Pada siklus II terjadi peningkatan pemahaman siswa mencapai $96 \%$. Hal ini sudah melebihi target yang di tetapkan. Begitu juga aspek afektif dan psikomotor terjadi peningkatan yang sangat bagus. Metode ini sangat cocok dengan mata pelajaran IPA. IPA adalah suatu deretan konsep serta skema konseptual yang berhubungan antara satu materi dengan materi lainnya yang tumbuh sebagai hasil eksperimentasi dan observasi, yang berguna untuk dieksperimenkan lebih lanjut (Connant dalam Usman, 2006:1).

\section{SIMPULAN DAN SARAN}

\section{Simpulan}

Dari paparan data dan hasil penelitian serta pembahasan di atas, maka dapat ditarik kesimpulan bahwa metode eksperimen dapat meningkatkan pemahaman siswa tentang materi IPA. Selain itu aspek afektif dan psikomotor siswa juga meningkat.

Saran.

Berdasarkan kesimpulan di atas, maka saran dapat diberikan pada penelitian ini adalah:

1. Untuk guru, agar dapat mencobakan dan menerapkan metode pembelajaran yang lebih bervariasi agar siswa dapat tertarik untuk mengikuti pembelajaran yang diberikan.

2. Guru juga dapat menggunakan metode ini untuk materi yang lainnya.

3. Untuk Kepala sekolah, dapat berupaya untuk meningkatkan sarana dan prasarana yang menunjang keberhasilan guru dalam meningkatkan hasil belajar siswa.

\section{DAFTAR PUSTAKA}

Abu Ahmadi . 2005. Strategi Belajar Mengajar. Bandung: CV. Pustaka Setia.

Depdiknas. 2006. kurikulam Tingkat Satuan Pendidikan Mata Pelajaran IPA. Jakarta: Depdiknas.

Imam Sriyono.1994.Teknik Belajar Mengajar. Jakarta. Rineka cipta.

Irfan.2008.http://irfan-na.blogspot.com/2007/11/tugas-mk-metode-pengajaran.html.(Diakses13 maret 2008). 
Martiningsih.2008.http://martiningsih.blogspot.com/2007/12/macam-macam-metodepembelajaran.html.(Diakses13 Maret 2008).

Muhammad Ali. 1992. Guru dalam Proses Belajar Mengajar. Bandung: CV. Sinar Baru Offset.

Muhibbin Syah. 2007. Psikologi Pendidikan. Bandung: PT. Remaja Rosdakarya.

Mulyani Sumantri. 1999. Strategi Belajar Mengajar. Jakarta: Universitas Terbuka

Nana Sudjana. 2004. Dasar-Dasar Proses Belajar. Bandung: Sinar Baru Algensindo.

Roestiyah. 2001. Strategi Belajar Mengajar. Jakarta: PT. Rineka Cipta.

Srini M Iskandar. 1997. Pendidikan Ilmu Pengetahuan Alam. Depdikbud.

Suryosubroto. 2002. Proses Bejar Mengajar Di Sekolah. Jakarta: PT.Rineka Cipta.

Syaiful Bahri Djamarah. 2006. Strategi Belajar Mengajar. Jakarta: PT. Rineka Cipta

Wina Sanjaya. 2006. Strategi Penbelajaran Berorientasi Standar Proses Pendidikan. Jakarta: Kencana Prenada Media Grup.

Winarno Surakhmad. 2000. Metedologi Pengajaran Nasionalr. Bandung: Jemarss.

Winata Putra. 2001. Strategi Belajar Mengajar. Jakarta: Universitas Terbuka

http://re-searchengines.com/art05-65.html.(Diakses 13 maret 2008).

http://pakguruonline.pendidikan.net/buku_tua_pakguru_dasar_kpdd_b12.html.(Diakses 13 maret 2008).

http://www.puskur.net/inc/mdl/050_Model_IPA_Trpd.pdf. (Diakses 6-februari-2008) 